\title{
Knowledge of Farm Women Regarding Health and Nutritional Practices
}

\author{
S.P. Dhoke ${ }^{1}$, Y.B. Shambharkar ${ }^{2}$, R.G. Nair ${ }^{1}$ and V.G. Dhulgand ${ }^{1 *}$ \\ ${ }^{1}$ Department of Extension Education College of Agriculture, Parbhani, Maharashtra, India \\ ${ }^{2}$ Department of Extension Education College of Agriculture, Akola, Maharashtra, India \\ *Corresponding author
}

\begin{abstract}
A B S T R A C T
Keywords

Knowledge, Health and nutritional practices, Farm women

Article Info

Accepted:

12 December 2017

Available Online:

10 January 2018

This study was purposively conducted in Achalpur taluka of Amravati district for the Knowledge and Adoption of Health and Nutritional Practices by Farm Women. 150 farm women were selected from 10 selected villages by using random sampling method. It is operationally define as the information gained by the individual farm women regarding general health and nutritional practices. majority $(64.00 \%)$ of the farm women respondents were having knowledge about the health and nutritional practices at extent of medium level followed by 18.66 per cent who were observed in high level of knowledge, whereas 17.33 per cent of them were in low knowledge of health and nutritional practices. It can be concluded that, majority of the farm women respondents were observed in medium level of knowledge level about health and nutritional practices.
\end{abstract}

\section{Introduction}

According to WHO, "Health is the state of complete physical, mental and social wellbeing and not merely and absent of disease or infirmity.'In the recent year, this statement has been amplified to include ability, to lead a socially and economically productive life. Recently a broader concept of health has been emerging that improving the quality of life which is an essential component.

India, being a country in developmental transition, faces the dual burden of pretransition diseases like under nutrition and infectious diseases as well as post-transition, lifestyle-related degenerative diseases such as obesity, diabetes, hypertension, cardiovascular diseases and cancers. According to recent National Family Health Survey (1.6) and UNICEF Reports (1.7), $46 \%$ of preschool children and $30 \%$ of adults in India suffer from moderate and severe grades of proteincalorie malnutrition as judged by anthropometric indicators.

Currently, India is in nutrition transition with $10 \%$ rural adults and $20 \%$ urban adults suffering from over nutrition leading to an emerging double burden of malnutrition (1.8). Humans need a wide range of nutrients to lead 
a healthy and active life. The required nutrients for different physiological groups can only be derived from a well-balanced diet. Components of the diet must be chosen judiciously to provide all the nutrients to meet the human requirements in proper proportions for the different physiological activities. The amount of each nutrient needed for an individual depends upon his/her age, body weight and physiological status. Adults need nutrients for maintenance of constant body weight and for ensuring proper body function. Infants and young children grow rapidly and require nutrients not only for maintenance but also for growth. They require relatively more nutrients (2-3 times) per kg body weight than adults. In physiological conditions like pregnancy and lactation, adult woman needs additional nutrients to meet the demand for fetal growth and maternal tissue expansion in pregnancy and milk secretion during lactation. These extra intakes of nutrients are essential for normal growth of infants in uterus and during early post-natal life.

\section{Materials and Methods}

The study was conducted in Amravati district of the Vidarbha region of Maharashtra state. Achalpur Panchayat samit was purposively selected based on more number of primary health centre in Amravati district. Achalpur taluka comprises of 68 villages out of which 10 villages were selected randomly based on having Primary Health Centre. The main objectives of the study was to measure the knowledge and adoption of farm women about health and nutritional practices which includes the different practices like, personal hygiene, sanitation, care of surrounding, care and diet of the person, food preservation. Therefore, it was felt necessary that the respondents in the study area must have the sufficient information of the family life. So, it was decided to select the married women. The married women as respondents were selected randomly from each selected village to constitute sample size of 150 respondents.

The Ex-post facto research design was used in the present study, statistically analyzed by using statistical techniques like frequency, percentage. For the study, the interview schedule based on the objectives of the study was prepared for collecting data from the respondents.

The main objective for this To study the knowledge of farm women regarding health and nutritional practices.

\section{Results and Discussion}

The data presented in Table 1 concluded that, amongst health practices for children, cent per cent of the respondents were having knowledge about importance of immunization of the child, bathing the child daily and giving the child enough safe water respectively. It was followed by majority of the farm women (76.66\%) and (74.66\%) who were having knowledge about regular health check-up of baby every month in baby clinic/health centre and washing the hands before holding and feeding the baby.

With regards to health practices for adults, majority of the farm women $(86.66 \%)$ and $(84.66 \%)$ were having knowledge about keeping the house clean by sweeping and swaddling daily and washing hands before preparing cooking and taking meals whereas, the farm women having knowledge about washing vegetables before cutting them were reported by majority i.e. 84.00 per cent. The respondents who were having knowledge about keeping the food items covered will protect from flies and dirt, taking boiling/filtered water prevents, the diseases caused by mosquitoes, bed bugs, house flies etc. can be prevented by keeping surrounding clean without water stagnation and trimming 
nails clean were $(78.66 \%), \quad(70.00 \%)$, $(63.33 \%)$ and $(60.00 \%)$ respectively.

Amongst nutrition practices for child health, cent per cent farm women were know about the importance of breast feeding for infant/baby followed by large majority of the respondents were aware about introducing of milk and milk products or eggs and egg products for growing child. The respondents $63.33,55.33,53.00$ and 42.00 per cent of the farm women were having knowledge about introducing solid food like (Khichri/ricedal) to 7 month age old child, daily consumption of rice, dal and vegetable for growing child, giving of Colostrums to new born baby and introducing of small quantities of soup, Juices, kheer etc. to baby's diet at 3 month stage.

Table.1 Knowledge of farm women about health and nutritional practices

\begin{tabular}{|c|c|c|c|}
\hline \multirow{2}{*}{$\begin{array}{l}\text { Sr. } \\
\text { No. }\end{array}$} & \multirow[t]{2}{*}{ Statement } & \multicolumn{2}{|c|}{ Knowledge (n=150) } \\
\hline & & Frequency & Percentage \\
\hline $\mathbf{A}$ & Health practices for children & & \\
\hline 1 & Immunization is must for good health of the child & 150 & 100.00 \\
\hline 2 & Bathing the child daily is good for health & 150 & 100.00 \\
\hline 3 & $\begin{array}{l}\text { Giving the child enough safe water for drinking } \\
\text { regularly }\end{array}$ & 150 & 100.00 \\
\hline 4 & $\begin{array}{l}\text { Washing the hands before holding and feeding the } \\
\text { baby is necessary }\end{array}$ & 112 & 74.66 \\
\hline 5 & $\begin{array}{l}\text { Regular health check-up of baby every month in baby } \\
\text { clinic/health centre is needed. }\end{array}$ & 115 & 76.66 \\
\hline B & Health practices for adults & & \\
\hline 6 & $\begin{array}{l}\text { Keeping the house clean by sweeping and swaddling } \\
\text { daily is necessary }\end{array}$ & 130 & 86.66 \\
\hline 7 & $\begin{array}{l}\text { The diseases caused by mosquitoes, bed bugs, house } \\
\text { flies etc. can be prevented by keeping surrounding } \\
\text { clean without water stagnation. }\end{array}$ & 95 & 63.33 \\
\hline 8 & $\begin{array}{l}\text { Trimming nails clean reduces many food boon } \\
\text { diseases. }\end{array}$ & 90 & 60.00 \\
\hline 9 & $\begin{array}{l}\text { Taking boiling/filtered water prevents many water } \\
\text { born diseases. }\end{array}$ & 105 & 70.00 \\
\hline 10 & $\begin{array}{l}\text { Keeping the food articles/items covered will protect } \\
\text { from flies and dirt. }\end{array}$ & 118 & 78.66 \\
\hline 11 & $\begin{array}{l}\text { Washing vegetables before cutting them is good for } \\
\text { health }\end{array}$ & 126 & 84.00 \\
\hline 12 & $\begin{array}{l}\text { Washing hands before preparing cooking and taking } \\
\text { meals is good. }\end{array}$ & 127 & 84.66 \\
\hline $\mathbf{C}$ & Nutrition practices for child health & & \\
\hline 13 & Colostrums should be given to new born baby & 80 & 53.00 \\
\hline 14 & Breast feeding for infant/baby is must & 150 & 100.00 \\
\hline 15 & $\begin{array}{l}\text { Introducing solid food like (Khichri/ricedal) has to be } \\
\text { given to } 7 \text { month age old child. }\end{array}$ & 95 & 63.33 \\
\hline 16 & Daily consumption of rice, dal and vegetable is & 83 & 55.33 \\
\hline
\end{tabular}




\begin{tabular}{|c|c|c|c|}
\hline & beneficial for growing child. & & \\
\hline 17 & $\begin{array}{l}\text { Introducing of small quantities of soup, Juices, kheer } \\
\text { etc. to baby's diet at } 3 \text { month stage. }\end{array}$ & 63 & 42.00 \\
\hline 18 & $\begin{array}{l}\text { Introducing milk and milk products or eggs and egg } \\
\text { products is good for growing child. }\end{array}$ & 130 & 87.00 \\
\hline D & Nutritional practices for adults & & \\
\hline 19 & Green leafy vegetables must be included in the diet. & 87 & 58.00 \\
\hline 20 & Sprouted pulses are more nutritious. & 70 & 46.00 \\
\hline 21 & $\begin{array}{l}\text { Introducing Cereal-Pulse combination in regular diet } \\
\text { in nutrition }\end{array}$ & 95 & 63.00 \\
\hline 22 & Consumption of milk and curds strengthen bones. & 84 & 56.00 \\
\hline 23 & Using jaggery in the diet reduces the iron deficiency. & 57 & 38.00 \\
\hline 24 & Fruits provide vitamins and minerals good for health. & 117 & 78.00 \\
\hline 25 & $\begin{array}{l}\text { Drinking 4-5 liters of water maintain the good } \\
\text { hygiene. }\end{array}$ & 63 & 42.00 \\
\hline 26 & $\begin{array}{l}\text { Mixing of Soybean with Jowar and Wheat during } \\
\text { grinding makes food more nutritious. }\end{array}$ & 90 & 60.00 \\
\hline
\end{tabular}

Table.2 Distribution of respondents according to their knowledge level about health and nutritional practices

\begin{tabular}{|c|c|c|c|}
\hline \multirow{2}{*}{ Sr. No. } & Category & \multicolumn{2}{|c|}{ Respondents $(\mathbf{n = 1 5 0})$} \\
\cline { 3 - 4 } & & Frequency & Percentage \\
\hline 1 & Low & 26 & 17.33 \\
\hline 2 & Medium & $\mathbf{9 6}$ & $\mathbf{6 4 . 0 0}$ \\
\hline 3 & High & 28 & 18.67 \\
\hline
\end{tabular}

As far as nutritional practices for adults are concerned, majority of the farm women $(78.00 \%)$ and $(63.00 \%)$ were having knowledge about importance of fruits which provides vitamins and minerals good for health and introducing cereal-pulse combination in regular diet respectively. The respondents who were having knowledge about mixing of Soybean with Jowar and Wheat during grinding makes food more nutritious, importance of green vegetables in diet and consumption of milk and curds which helps to strengthen bones were reported by the 60.00 and 58.00 and 56.00 per cent of the respondents respectively. Less than half of the respondents $(46.00 \%), \quad(42.00 \%)$ and $(38.00 \%)$ were known about the sprouted pulses are more nutritious, drinking of 4-5 liters of water and using jaggery in the diet which reduces the iron deficiency.

From the above findings it can be concluded that majority of the respondents were having knowledge about health practices of child and health practices of adults compared to nutritional practices of child and nutritional practices for adults.

\section{Knowledge level}

Distribution of the respondents according to their adoption level presented in Table 2 it could be seen that majority $(64.00 \%)$ of the farm women were having knowledge about the health and nutritional practices at extent of medium level followed by 18.66 per cent who 
were observed in high level of knowledge, whereas 17.33 per cent of them were in low knowledge of health and nutritional practices.

It can be concluded from the above findings that, majority of the farm women respondents were observed in medium level of knowledge level about health and nutritional practices.

Little more than one fourth $(25.33 \%)$ of the respondents had high, followed by little more than half $(51.33 \%)$ were observed in medium and the remaining $(23.33 \%)$ were in low knowledge level regarding health and nutritional practices.

References
Ashwini Shintre, 2009. Attitude of women members towards self-help group. M.Sc. (Agri.) Thesis (Unpub.), Dr. PDKV, Akola.

Kiran Vani, 2007. Knowledge and Adoption of Selected Health and Nutritional Practices by Rural Women in Belgaum District, Karanataka M.Sc.(Agri.) Thesis (unpub), Uni. of Agril. Sciences, Dharwad.

Swetha Suman, Usha Malagi, Rama K. Naik and Hasabi, I.S. 2007. Clinical health status prevailing complications among chronic renal failure patients. The Ind. J. Nut. Dietics. 44: 236-243.

\section{How to cite this article:}

Dhoke, S.P., Y.B. Shambharkar, R.G. Nair and Dhulgand, V.G. 2018. Knowledge of Farm Women Regarding Health and Nutritional Practices. Int.J.Curr.Microbiol.App.Sci. 7(01): 14881492. doi: https://doi.org/10.20546/ijcmas.2018.701.181 